\title{
Läbilõikeline ülevaade üliõpilaste hinnangutest Tartu Ülikooli õpetajakoolituse õppekavade sidususele 2014.-2018. aastal
}

\author{
Liina Malva ${ }^{a 1}$, Äli Leijen ${ }^{a}$ \\ ${ }^{a}$ Tartu Ülikooli haridusteaduste instituut
}

\begin{abstract}
Annotatsioon
Õpetajakoolitus on praktikaga tihedalt seotud õppevaldkond, kuid siiski on teooria ja praktika sidumine õpetajakoolituses veel paljudes riikides proovikivi (Darling-Hammond, 1999; Hammerness \& Klette, 2015). Tartu Ülikoolis hakati selle kitsaskohaga ulatuslikult tegelema 2013. aastast, uuendades õpetajakoolituse alus- ja praktikamoodulit. Selleks, et läbi aastate tehtud muudatuste tulemuslikkust seirata, on alates 2014. aastast igal sügisel alusmooduli üliõpilaste seas ( $n=572)$ kogutud andmeid nende hinnangute kohta õppekava sidususele. Tulemused näitavad, et üliõpilaste hinnangul on märgatavalt paranenud nii teoreetiliste õppeainete kooskõla praktikal kogetuga kui ka võimalused õppekava osi omavahel siduda. Samas leiti, et ülikooli õppetöös on liiga vähe tegevusi, mis valmistaksid üliõpilasi ette õppija arengust lähtumiseks õpetajatöös. Ülikooli õppeained keskenduvad enam õppe kavandamisele ja analüüsile, vähem tegeletakse õppetöö tegevustega.
\end{abstract}

Võtmesõnad: õpetajakoolitus, õpetajakoolituse alusained ja praktika, õppekava sidusus

\section{Sissejuhatus}

Õpetamine kui uurimisvaldkond on viimase 50 aasta jooksul läbi teinud muutusi, liikudes õpetajate omaduste uurimiselt õpetaja käitumise ja hiljem õpetaja mõtlemise ja teadmiste uurimise suunas (Grossman \& McDonald, 2008). Viimasega seoses on õpetajate kontseptuaalsed teadmised (nii ainesisu kui ka pedagoogilised teadmised) saanud ka õpetajakoolituse esmaõppes väga palju tähelepanu. 2000ndate algusest alates on hakatud kritiseerima õpetajakoolituste ülemäärast teooriakesksust (vt nt Korthagen, 2001). Õpetamise interaktiivse olemuse tõttu on oluline teoreetiliste teadmiste kõrval rõhutada

Tartu Ülikooli haridusteaduste instituut, Salme 1a, 50103 Tartu; liina.malva@ut.ee. 
ka nende teadmiste rakendamist praktilistes olukordades. Sellest lähtuvalt on leitud, et õpetajakoolituse õppekavade üks olulisi ülesandeid on pakkuda õppijatele teoreetiliste õppeainete kõrval ka võimalusi õpetamist harjutada ja puutuda kokku reaalse õpetajatööga (Grossman \& McDonald, 2008). Üks võimalus teooria paremaks seostamiseks praktikaga on Grossman ja McDonald (2008) pakkunud välja tuumpraktikate kontseptsiooni (ingl k core practice), mille järgi keskendutakse õpetajakoolituses õpetajatöö kõige olulisematele terviklikele tegevustele. Arvukatest õpetajakoolituse uuringutest ja arendustööst hoolimata rõhutatakse siiski ka siiani õpetajakoolituse teooria ja praktika liigset lõhestumist (Grossman, Hammerness, \& McDonald, 2009b; Zeichner, 2010; Darling-Hammond, 2014). Samas on aga Krull (2003) toonud välja, et teoreetilised õpingud mängivad õpetamises olulist rolli ainult siis, kui neid on võimalik kasutada praktikas.

Tartu Ülikoolis on viimasel seitsmel aastal viidud õpetajakoolitusse sisse muudatusi, mille eesmärk on paremini seostada õpetajakoolituse esmaõppe ainekursusi ja praktikat. Selleks loodi 2013. aastal õpetajakoolituse alus- ja praktikamoodul, mis peaks soodustama nii õppeainetevahelist kooskõla kui ka praktika paremat seostatust ülikooli õppeainetega. Lisaks uuendati täielikult 2017. aastal praktikaainet, mille eesmärk on keskenduda vaid väga olulistele ópetajatöö tegevustele, rakendades tuumpraktikate kontseptsiooni. Praktikaaine uus ülesehitus võimaldab praktika teemasid ülejäänud õppeainetega süsteemselt siduda. Selleks, et mõista, kuivõrd on kõik need muudatused Tartu Ülikooli õpetajakoolituses rakendunud, on oluline õpingute kohta süsteemset tagasisidet koguda. Sellest lähtuvalt on siinse uurimuse eesmärk anda ülevaade Tartu Ülikooli üliõpilaste hinnangutest õpetajakoolituse viie aastakäigu (2014-2018) õppekavade sidususele. Järgnevalt tutvustame õppekava sidususe tahke, millele uuringus keskendume.

\section{Õpetajakoolituse õppekavade sidusus}

Hammerness (2013) on välja toonud, et sidus õpetajakoolituse õppekava on organiseeritud eesmärgipäraselt, tänu millele on üliõpilastel võimalus läbida aineid struktureeritult ja kindla sihiga. Sealjuures on sidusal õppekaval kindel suund, süstemaatilised seosed ja üheti mõistetav tähendus (Buchman \& Floden, 1991). Newmann, Smith, Allenworth ja Bryk (2001) on leidnud, et sidus õppetöö toetab õpimotivatsiooni, kuna uute teadmiste omandamine käib samm-sammult. Siinse artikli raamistik tugineb Hammernessi (2006) lähenemisele, mille järgi on õpetajakoolituse õppekavade sidususel kaks olulist komponenti: 1) õppeainete sidusus ning 2) teoreetiliste õppeainete ja praktika sidusus. Hammerness (2006; vt ka Muller, 2009) on sealjuures rõhutanud, 
et õppeainete omavahelise seostatuse puhul on olulised nii strukturaalne kui ka kontseptuaalne lähenemine. Esimese puhul pööratakse tähelepanu õppeainete praktilisele organiseerimisele õppekavas ja tunniplaanis nii, et need tervikuna toetaksid üliópilaste teadmiste pidevat ja loogilist täiendamist. Teise ehk kontseptuaalse lähenemise puhul pööratakse aga rohkem tähelepanu õppeainete sisule ehk ühtsele vaatele õpetamise kohta, mida läbivalt õpingute jooksul käsitletakse.

Õppekavade sidusus eeldab õppejõudude ja praktikajuhendajate jagatud põhimõtteid õpetamise kohta (Tatto, 1996). Eriti oluline on see selleks, et üliõpilased oskaksid praktikal nähtut ja kogetut paremini mõista ning tulemuslikuma õpetajatöö saavutamiseks lahti mõtestada (Hammerness, 2006). Seetõttu on vaja, et õpetajakoolituse õpingute teoreetiliste õppeainete põhiideed ja praktikal kogetu oleksid omavahel seotud ning jagaksid ühtset visiooni (Darling-Hammond, 1999; Grossman, Hammerness, McDonald, \& Ronfeldt, 2008). Õpetajakoolituse ühtse vaate saavutamise aluseks on hea koostöö ülikooli ja praktikakooli vahel. Sealjuures on soovitav praktikakoolideks valida sellised õppeasutused, mille puhul on teada järjepidev, tulemuslik ja ühtne õpetamisstiil. Hea praktikakool toetab üliópilast selles, mida ta on ülikoolis õppinud. Kui koolis saadud kogemused vastanduvad teoreetilistele õpingutele, on tulevastel õpetajatel väga raske oma tegevust mõtestada ja eesmärke seada (Hammerness, 2013). Samas tuleb silmas pidada, et õpetajatöös esineb tihti ootamatuid olukordi, mis nõuavad õpetajatelt pidevat avastamist ja arenemist, mistõttu ei tohi ühegi praktikakooli õpetamisstiil olla paindumatu (Buchmann \& Floden, 1991).

Õpetajakoolituse õppekavade sidususe tugevdamiseks on Grossman ja McDonald (2008) pakkunud välja keskse tuumpraktika põhimõtte. Kesksed tuumpraktikad ehk õpetajatöö olulised tegevused määravad õppekava raamistiku, mis toetab üliõpilaste professionaalsete teadmiste, oskuste ja identiteedi kujunemist. Sellisteks tegevusteks võivad olla näiteks klassis arutelu juhtimine või rühmatöö organiseerimine ja juhendamine, aga ka õppejõu poolt hea õpetamise mudeldamine (Grossman et al., 2009b). Ball ja Forzani (2009) on tuumpraktikate tegevustena nimetanud ka tegevusi õppetundidest väljaspool, nagu lastevanematega suhtlemine ja õppetöö planeerimine. Samas on toodud välja, et ükski õpetajakoolituse uurija ei ole siiani neid tegevusi üksikasjalikult defineerinud. Konkreetsetes tegevustes kokkuleppimine on keeruline seetõttu, et õpetamine on tugevalt sõltuvuses kontekstist (Ball \& Forzani, 2009). Seetõttu on hoopiski määratud tuumpraktikate kui kontseptsiooni ühtsed tunnused. Grossmanni jt (2009b) järgi on tuumpraktikad tegevused: 1) mis esinevad õpetamise käigus tihti, 2) milles on võimalik ennast pidevalt arendada ning 3) mis tuginevad teaduspõhistele tulemustele. Õppekava ülesehitamine ümber 
selliste tuumpraktikate annab üliõpilastele võimaluse pidevalt täiendada, seostada oma professionaalseid teadmisi ja oskusi (Grossman \& McDonald, 2008; Grossman et al., 2009b).

\section{Võimalused jagatud visiooni harjutamiseks}

Eespool kirjeldatud õppekava sidususe saavutamiseks on väga oluline roll õpetajatöö harjutamisel (Leijen, Kullasepp, \& Ots, 2013; Grossman et al., 2009b; Stürmer, Könings, \& Seidel, 2013). Harjutamine on tulemusrikas siis, kui see toimub võimalikult sarnaselt reaalse situatsiooniga, seetõttu võiks näiteks õpilaste tööde hindamisel kasutada näiteid päris õpilastöödest. On leitud, et õpilaste tulemused on standardtestides kõrgemad nende alustavate õpetajate käe all, kelle õpetajakoolitus on väga tugevalt olnud seotud praktika ja reaalse elu näidetega (Boyd, Grossman, Lankford, Loeb, \& Wyckoff, 2009). Lisaks mõjutab pedagoogiline praktika õpetaja identiteedi kujunemist, kuna praktika käigus pannakse proovile oma teoreetilised teadmised ja professionaalsed oskused (Poom-Valickis \& Löfström, 2014; Anspal, Leijen \& Löfström, 2019).

Harjutamine ei pea aga alati toimuma praktikakoolis. Õpetamine on valdkond, kus praktikaga seotud tegevusi on võimalik harjutada ning enda teadmisi ja oskusi seeläbi tugevdada ka väljaspool kooli- või lasteaiakeskkonda. Sellest hoolimata on Ameerika Ühendriikide näitel leitud, et just õpetajatel on esmakoolituses vähem selliseid võimalusi, võrreldes näiteks psühholoogidega (Grossman et al., 2009a). Grossman ja Loeb (2010) on andnud ülevaate kolmest Ameerika Ühendriikide ülikoolist, kus õppekavad on üles ehitatud nii, et iga ainet läbivad varem kokku lepitud tuumpraktikate teemad. Nende alla kuuluvaid tegevusi katsetatakse seega mitmes õppeaines, mistõttu ei õpita ülikoolis vaid traditsiooniliselt lugemise, kirjutamise ja arutlemise kaudu. Peale selle on ka leitud, et need õpetajad, kellel oli oma õpingute ajal võimalusi konkreetseid tegevusi läbi katsetada, olid oma esimesel tööaastal efektiivsemad (Boyd, Grossman, Lankford, Loeb, \& Wyckoff, 2006).

Üks näide, kuidas ülikooli õppeaineid tugevamini praktikaga siduda, on kasutada üliõpilaste enda praktikakogemusi. Hammerness (2006) on kirjeldanud, kuidas Stanfordi Teacher Education Programi õpetajakoolitusel paluti üliõpilastel kaasa võtta oma praktikakooli õpilastööde näidiseid. Pärast tööde analüüsimist püüti koos õppejõuga leida strateegiaid ja lahendusi, kuidas neid õpilasi aidata saaks ning millele järgmisena õpetamisel keskenduda. Kogu analüüs ning strateegiate koostamine tugines teadusartiklitele ja ka üliõpilaste enda kogemustele õpetajana. Kirjeldatud näide illustreerib, kuidas õpetajatöö praktiline pool ei pea esinema ainult koolis, vaid neid kogemusi 
saab mõtestatult integreerida ka ülikooli õppeainetesse. Siiski on aga leitud, et just õpetajakoolituse õppejõud näevad sageli üksnes praktikakooli vastutavana selles, et pakkuda üliõpilastele praktilisi ja reaalse elu lähedasi tegevusi (Grossman et al., 2009b).

\section{Õpetajakoolituse sidususe empiirilised uuringud}

Õpetajakoolituse õppekavade sidusust uuritakse peamiselt kahel viisil: vaatluste ja küsimustike kaudu. Vaatluse kaudu on võimalik uurida näiteks reaalsete õpetamistegevuste kaasamist ülikooliainetes. Jenset, Canrinus, Klette ja Hammerness (2018b) korraldasid vaatlusi võõrkeele ja matemaatika didaktikaainetes, et kirjeldada õppejõudude tegevusi õpilaste õppimise analüüsimiseks. Selleks püüdsid vaatlejad õppeainetes märgata näiteks õpilaste tööde, õpetaja kõne või õppetunni analüüsimist. Vaatlusmärkmeid tehti vabas vormis, mis tähendab, et ühe vaatlustunni lõpuks oli vaatlejal 10-15 lehekülge märkmeid. Uurimuse tulemustest selgus, et isegi kui üliõpilastele anti võimalusi õpilaste töid analüüsida, tehti seda pigem aineteadmistest lähtuvalt, mitte veatüüpe analüüsides ega arutledes, kuidas õpilasi aidata. Vaatluste tulemusel on Jenset jt (2018b) soovitanud õpetajakoolitusse rohkem kaasata õppimisprotsessi käsitlevaid teemasid ja tegevusi reaalse koolielu kontekstist. Ühe projekti käigus koguti vaatlusega andmeid kaheksa õpetajakoolituse programmi kohta viiest riigist (Klette, Hammerness, \& Jenset, 2017). Leiti, et kõikides nendes õpetajakoolituse programmides on puudus õpetamise harjutamisest, õpilaste õppimise analüüsimisest (nt kodutööde analüüsimine) ja õpetamise mudeldamisest.

Vaatluse abil on seega õppekavade sidususe kohta võimalik saada mitmesugust infot selle kohta, mis õppeainetes toimub, kuid sellel andmekogumise viisil on ka piiranguid. Esiteks väljendavad tulemused vaid vaatleja arusaama sellest, mis õppeaines toimus. Nähtud tegevuste puhul ei olnud tegelikult selge, mis eesmärgil õppejõud neid kasutas (Jenset et al., 2018b). Teades, mis oli õppejõu eesmärk ning kuidas tegevus aines teostus, oleks võimalik sügavamalt analüüsida õppejõudude kavatsuste kooskõla reaalsusega või erinevust sellest. Teiseks on Jenset jt (2018b) vaatluse puhul toonud välja ajalise faktori - nimelt tehti nende projekti vaatlusi kolme nädala jooksul, mil ei pruukinud kõik uuritavad teemad õppeainetes kasutusele tulla, teades, et õppeained kestavad terve semestri. Jättes aga kõrvale piirangud, siis vaatlus on kindlasti üks oluline meetod just spetsiifiliste õpitegevuste uurimiseks (sh tuumpraktikad), et saada rohkem infot ülikooli õppeainete ja praktika seotuse kohta.

Teine levinud viis õppekavade uurimiseks on küsimustike kasutamine. Küsimustikud on küll enesekohased (ehk lähtuvad siinses kontekstis üliõpilaste 
arvamustest), kuid nende kasutamisel on omad eelised. Canrinus, Bergem, Klette \& Hammerness (2017) on toonud välja, et isegi kui ülikool on kavandanud õppekavad sidusaks, ei pruugi üliõpilased õppides seda sellisena tajuda. Uuringud on näidanud, et üliõpilaste hinnangud õppekavale mõjutavad nii nende akadeemilisi tulemusi kui ka seda, millisena nad näevad oma õppimiskogemust kõrgkoolis (Prosser, Ramsden, Trigwell, \& Martin, 2003). Sellest tulenevalt saab ka õppekavade sidususe uurimisel kasutada üliõpilastele suunatud küsimustikke ning seejuures ei tohi alahinnata küsimustike enesekohast olemust, kuna just üliõpilased on need, kes kogevad õppekava rakendumist (Raudenbush, 2008). Üliõpilaste arvamused on oluline allikas, selleks et mõista õpetajakoolituse õppekavade olemust.

Ühes sellises uurimuses (vt Canrinus et al., 2017) võrreldi Oslo (Norra), Stanfordi (USA), Helsingi (Soome), Santiago (Pontificia Universidad Católica de Chile in Santiago, Tšiili) ja Varona (Insitutio Superior Pedagógico Enrique José Varona, Kuuba) õpetajakoolituse õppekavade sidusust üliõpilaste hinnanguil CATE (Coherence and Assignment Practices in Teacher Education) küsimustikuga (Hammerness, Klette \& Bergem, 2014), mis koosneb neljast alaskaalast: 1) võimalused siduda õpitavat praktilise õpetajatööga, 2) üliõpilaste tajutud õpetajakoolituse õppeainete sidusus, 3) võimalused siduda õppekava eri osi ning 4) üliõpilaste tajutud sidusus ülikooli õppeainetes õpitu ja praktikal kogetu vahel. Tulemused näitasid, et üliõpilased hindasid kõige madalamalt ülikooli õppeainete seotust praktikaga. See tulemus toetab uurijate kriitikat, et õpetajakoolituse programmid on üles ehitatud liiga teoreetiliste ja abstraktsetena, pöörates liiga vähe tähelepanu sellele, mida üliõpilased pärast lõpetamist koolis tegema hakkavad (Zeichner, 2010).

Üheks lahenduseks on pakutud välja õpetamise mudeldamist ülikooli õppejõudude poolt, mis valmistaks üliõpilasi kooli minekuks paremini ette (Korthagen, Loughran, \& Russell, 2006). Seetõttu on CATE küsimustikus välja töötatud ka õpetamistöö tegevuste alaskaala, mille kaudu saab teavet konkreetsete tegevuste kaasamisest ülikooli õpingutes (Canrinus, Klette, Hammerness, \& Bergem, 2019). Samas on Grossmann et al. (2008) öelnud, et praktika ja teooria sidumist ei tohiks vaadata läbi kvantiteedi prisma, vaid pöörata tähelepanu nende tegevuste eesmärgipärasusele ja rakendamise mõttekusele.

Juba mainitud uurimuses, kus võrreldi viie riigi õpetajakoolitusi, selgus, et Oslo ülikooli õpetajakoolituse õppeainete sidusust hinnati teiste riikidega võrreldes märgatavalt madalamalt. Uuringu tegijad Canrinus et al. (2017) on arutlenud, et küsimustiku täitmise ajal toimusid nende õppekavades ulatuslikud muudatused, millega uuendati nii ülikooli- kui ka praktikaaineid. Üheks oletatavaks põhjuseks on nimetatud ka õppehoonete füüsilist distantsi, mille tõttu väheneb tõenäosus õppejõududevaheliseks koostööks (Kraut, Fussell, 
Brennan, \& Siegel, 2002). Autorid toovad välja pikaajalise uurimuse vajaduse, et jälgida muutuste mõju või selle puudumist aastast aastasse.

Kuna CATE küsimustik on võimaldanud koguda rikkalikku teavet õpetajakoolituse õppekavade sidususe kohta eri riikides, otsustati Tartu Ülikooli õpetajakoolituse läbilõikelises uuringus kasutada sama küsimustikku. Sellest lähtuvalt on siinse uurimuse eesmärk anda ülevaade Tartu Ülikooli üliõpilaste hinnangutest õpetajakoolituse õppekavade sidususele viies aastakäigus (20142018). Vastuseid otsiti järgmistele uurimisküsimustele.

1. Millised on üliõpilaste hinnangud õpetajakoolituse õppekavade sidususele, võrreldes 2014., 2016. ja 2018. aastal kogutud hinnanguid?

2. Millised võimalused on õpetajakoolituse üliõpilastel ülikooli õppeainetes harjutada õpetajatöö tegevusi, võrreldes 2014.-2018. aastakäikude üliõpilaste hinnanguid?

\section{Meetod}

Siinne uuring on tehtud läbilõikelise uuringuna, kasutatud on sihipärast valimit ning kvantitatiivset uurimisviisi. Järgnevalt antakse esmalt ülevaade uurimuse kontekstist ning seejärel kirjeldatakse valimit, mõõtevahendit ja töös kasutatud andmeanalüüsi meetodeid.

\section{Uuendused Tartu Ülikooli õpetajakoolituse õppekavades}

Alates 2013/2014. õppeaastast on Tartu Ülikooli õpetajakoolituse õppekavadesse sisse viidud olulisi muudatusi, mis aitaksid varasemast paremini seostada ülikooli teoreetilisi õpinguid praktikakooli kogemustega. Alustati õpetajakoolituse õppekavade ühtse alusmooduli (24 EAP) rakendamist, mida täiendas iga eriala praktikamoodul (24 EAP) (Leijen \& Pedaste, 2018). Võttes aluseks Tartu Ülikooli õpetajahariduse arengukava 2012-2015 ning õpetaja kutsestandardi, identifitseeriti alusmoodulit läbivad kolm teemavaldkonda (Pedaste, Pedaste, Lukk, Villems, \& Allas, 2013): 1) ópetaja kutse-eetika ja identiteet, 2) teaduspõhine lähenemine õpetamisele ning 3) õppimine ja motiveerimine. Peale läbivate teemade püüti alusmoodulis tugevdada ka struktuuriüksustevahelist koostööd, kaasates ainete õpetamisse eri teaduskondade õppejõudusid. Muudatused puudutasid eelkõige õppekavade ainete üldist sidusust.

Teine suurem muudatus viidi sisse praktikamoodulisse. Nimelt anti üliõpilastele ühes praktikaaines võimalus alustada oma kaks aastat kestvaid magistriõpinguid kohese praktikaga, mida alustati õppetöö esimesel nädalal ning praktikakoolis veedeti iga kahe nädala jooksul vähemalt üks päev. Lisaks sellele suurenes ka praktika kogumaht õpingute jooksul (varasema 15 EAP asemel 
24 EAPd). Sellised muudatuseed andsid üliõpilastele rohkem aega ja ka võimalusi tutvuda oma tulevase tööga, mõista paremini õpetajaks olemist ning elada sisse haridusasutuse igapäevaellu (Pedaste et al., 2013). Praktikamooduli läbimine muude õppeainetega samal ajal tugevdab ülikooli õppeainetes õpitu mõtestamist ja rakendamist ehk aitab paremini luua seoseid teooria ja praktika vahel.

Õpetajakoolituse õpingute arendamiseks on pidevalt võetud arvesse üliõpilaste tagasisidet ja tehtud arvukaid töökoosolekuid alusmoodulit õpetavate õppejõududega. Üks suurimaid muudatusi toimus aga 2017/2018. õppeaasta alguses, kui täielikult uuendati ühe praktikaaine ülesehitust ja sisu eesmärgiga siduda praktikat veelgi paremini alusmooduli teoreetiliste õppeainetega. Muudatuste aluseks võeti õpetajate tuumpraktikate kontseptsioon ning kirjanduse põhjal defineeriti seitse tuumpraktikat, mille ümber õppeaine „Pidev pedagoogiline praktika“ üles ehitati: õpimotivatsiooni toetamine, kujundav hindamine, õpetaja-õppija suhe, teistest eristuv õppija, koolikliima, eestvedamine ja juhtimine ning õpetaja heaolu. Nende teemade kohta said üliõpilased kõigepealt alusmooduli õppeainetest teoreetilise tausta ning seejärel tuli neil sooritada koolides vaatlusülesanded. Pärast teooria óppimist ja vaatlemist oli üliõpilastel võimalus iga tuumpraktika teemaga seotud õpetamistegevusi ise läbi teha, millele järgnes põhjalik refleksioon (sh seostamine teooriaga ja analüüs).

\section{Valim}

Uurimuse raames koguti andmeid 2014., 2015., 2016., 2017. ja 2018. aastal Tartu Ülikooli õpetajakoolituse õppekavade üliõpilastelt, kes olid sel ajal lõpetamas õpetajakoolituse alusmooduli viimast ainet. Selleks ajaks pidi neil suure tõenäosusega olema tehtud ka praktikamooduli ained ning ainealased didaktikaained. Elektrooniline küsimustik saadeti nendele õpetajakoolituse üliõpilastele, kes olid registreeritud õpetajakoolituse alusmooduli viimasele õppeainele. Andmeid koguti igal aastal sügissemestri teises pooles (novembris-detsembris; joonis 1) ning uurimuses osalemine oli vabatahtlik.

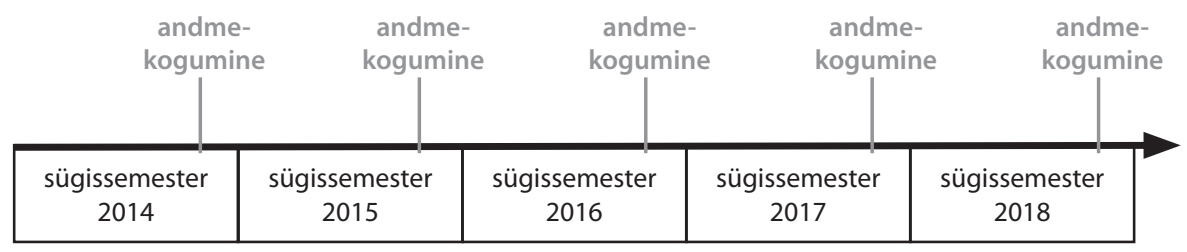

Joonis 1. Ajajoon andmekogumise visualiseerimiseks. 
Kokku osales 2014., 2015., 2016., 2017. ja 2018. aastal andmekogumises vastavalt 106, 102, 63, 136 ja 165 üliópilast (vt tabel 1). Kuna teatud erialade õppekavad on seoses alusmooduli rakendamisega aastatega muutunud (nt eripedagoogika), erinevad kohati ka aastate lõikes küsimustikule vastanud üliõpilased. Valimis osalenud magistriõppe üliõpilased alustasid õpetajakoolitust alles magistritasemel, õppides varem ainult eriala aineteadmisi. Küsimustiku vastamine magistritasemel toimus nende teisel óppeaastal kolmanda semestri lõppedes. Bakalaureuseõppekavad, nagu koolieelse lasteasutuse õpetaja ning kutseõpetaja, olid küsimustikule vastamise ajal kolmanda aasta tudengid. Klassiõpetaja, mis on integreeritud õppekava, on uuringu valimi ülevaates paigutatud magistritaseme alla, kuna need üliõpilased õppisid küsimustikule vastamise ajal kas neljandal või viiendal aastal ehk olid lõpetamas magistriõpet.

Tabel 1. Küsimustikule vastajate arvud erialati

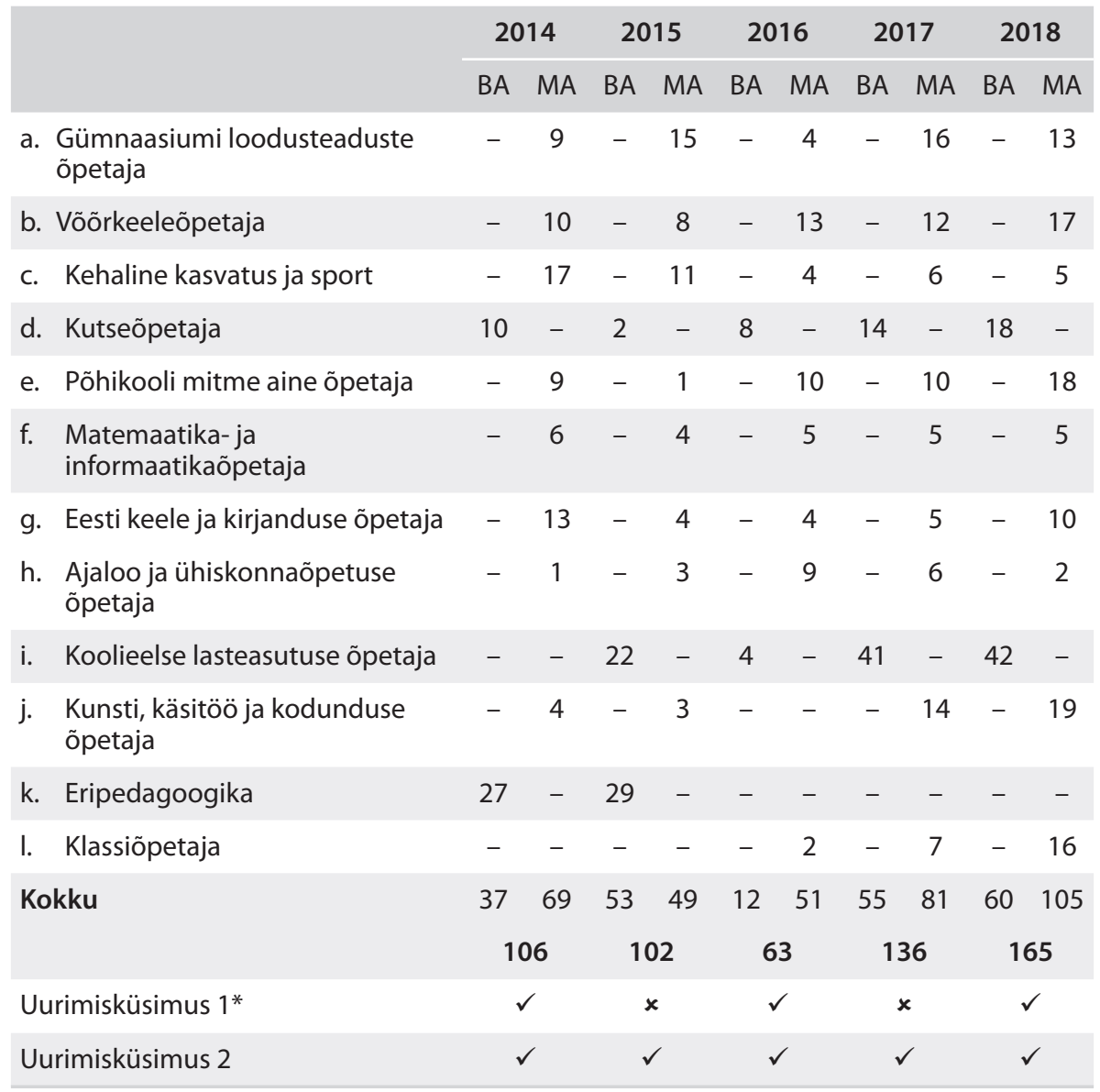

* 2015. aastal koguti andmeid vaid instrumendi esimese osaga, mis ei anna piisavalt materjali 1. uurimisküsimusele vastamiseks. Seetõttu otsustati 1. uurimisküsimusele vastamiseks kasutada 2014., 2016. ja 2018. aasta andmeid. 


\section{Mõõtevahend}

Andmeid koguti CATE (Coherence and Assignment Practices in Teacher Education) küsimustikuga (Hammerness, Klette \& Bergem, 2014), kuna varem kasutatud struktureeritud küsimustiku kasutamine võimaldab lühikese aja jooksul koguda andmeid suurelt valimirühmalt. Küsimustiku kasutamisel on tulemused arvulised ning sõltuvad vähe uurija enda tõlgendustest. CATE küsimustiku loomisel tugineti juba varem välja töötatud küsimustikule New York City Pathway Study (Boyd et al., 2006b), mis uurib õpetajakoolituse programmide omadusi New Yorgis. Seda juba välja töötatud küsimustikku täiendasid CATE küsimustiku autorid oma õppekavade sidususe definitsiooni järgi: „õppekava sidusus on protsess, milles kõik õppekava ained, nii teoreetilised kui ka praktilised, on välja töötatud hea õpetamise ühtsele visioonile tuginedes" (Canrinus et al., 2017; lk 315). Seetõttu pöörati tähelepanu, et CATE küsimustik kataks nii sidususe ülikoolis toimuvate õppeainete vahel, nende ainete seose praktikakogemustega kui ka üliõpilaste võimalused kogeda praktilise õpetajatöö ehk tuumpraktikate tegevusi. Selline küsimustiku ülesehitus tagab nii kontseptuaalse kui ka strukturaalse sidususe vaatenurga ning teooria ja praktika sidususe (Hammerness, 2006; Muller, 2009). Küsimustik kohandati eesti keelde 2014. aastal ning seda protsessi on täpsemalt kirjeldatud Malva (2015) metoodika peatükis.

CATE küsimustik koosneb neljast alaskaalast ja 29 väitest, mille kohta on ülevaade tabelis 2 ning täispikkuses instrument on esitatud lisas A. Esimesele uurimisküsimusele vastamiseks kasutati II, III ja IV alaskaalat ning teisele uurimisküsimusele vastamiseks I alaskaalat. Uurimisinstrumendi reliaabluse hindamiseks kasutati Cronbachi $\alpha$ mõõdikut. Reliaablust hinnatakse heaks, kui Cronbachi $\alpha$ väärtused jäävad vahemikku 0,7 $\leq a \leq 0,9$ (Field, 2009). Siinses töös jäi Cronbachi $\alpha$ küsimustiku II ja III alaskaala puhul vahemikku 0,78-0,88, mida võib lugeda heaks. IV alaskaala reliaablus oli madalam, jäädes vahemikku 0,56-0,63. Üheks põhjuseks võib olla väike väidete arv alaskaalas. 
Tabel 2. Ülevaade CATE ankeedi alateemadest

\begin{tabular}{|c|c|c|c|c|c|}
\hline Alaskaala & Käsitletud teemad & $\begin{array}{c}\text { Väidete } \\
\text { arv }\end{array}$ & Skaala & \multirow{2}{*}{\multicolumn{2}{|c|}{$\begin{array}{l}\text { Cronbach a } \\
\text { Kasutati } \\
\text { ainult } \\
\text { üksikväiteid }\end{array}$}} \\
\hline $\begin{array}{l}\text { Võimalused } \\
\text { siduda } \\
\text { õpitavat } \\
\text { praktilise } \\
\text { õpetaja- } \\
\text { tööga }\end{array}$ & $\begin{array}{l}\text { - tunnikava } \\
\text { väljatöötamine, } \\
\text { - õpilaste } \\
\text { tööde näidiste } \\
\text { analüüsimine, } \\
\text { - kasutatavate } \\
\text { õppematerjalide } \\
\text { uurimine. }\end{array}$ & 10 & $\begin{array}{c}1 \text { - polnud üldse } \\
\text { võimalusi } \\
2 \text { - defineerimata } \\
3 \text { - defineerimata } \\
4 \text { - oli väga palju } \\
\text { võimalusi }\end{array}$ & & \\
\hline $\begin{array}{l}\text { II Tajutud } \\
\text { sidusus } \\
\text { õppeainete } \\
\text { vahel }\end{array}$ & $\begin{array}{l}\text { - õpetajakoolituse } \\
\text { terviklikkus, } \\
\text { - arusaama } \\
\text { järkjärguline } \\
\text { kujunemine, } \\
\text { - õppejõudude } \\
\text { teadlikkus teistes } \\
\text { ainetes toimuvast. }\end{array}$ & 10 & $\begin{array}{l}1 \text { - ei nõustu üldse } \\
2 \text { - pigem ei nõustu } \\
3 \text { - pigem nõustun } \\
4 \text { - nõustun täielikult }\end{array}$ & $\begin{array}{l}2014 \\
2016 \\
2018\end{array}$ & $\begin{array}{l}0,82 \\
0,88\end{array}$ \\
\hline $\begin{array}{l}\text { III Võimalused } \\
\text { siduda } \\
\text { õppekava } \\
\text { eri osasid }\end{array}$ & $\begin{array}{l}\text { - seosed õppeainete } \\
\text { eri teemade vahel, } \\
\text { - seosed } \\
\text { õppeainetes } \\
\text { õpitavate teemade } \\
\text { vahel, } \\
\text { - iseenda õppimise } \\
\text { reflekteerimine. }\end{array}$ & 5 & $\begin{array}{c}1 \text { - polnud üldse } \\
\text { võimalusi } \\
2 \text { - defineerimata } \\
3 \text { - defineerimata } \\
4 \text { - oli väga palju } \\
\text { võimalusi }\end{array}$ & 2018 & 0,80 \\
\hline $\begin{array}{l}\text { IV Tajutud } \\
\text { sidusus } \\
\text { ülikooli } \\
\text { ainete ja } \\
\text { praktika } \\
\text { vahel }\end{array}$ & $\begin{array}{l}\text { - teoreetilistes } \\
\text { ainetes õpitud } \\
\text { teooriate ja } \\
\text { õppemeetodite } \\
\text { katsetamine } \\
\text { praktikal, } \\
\text { - praktikal õpitu } \\
\text { peegeldumine } \\
\text { õppeainetes. }\end{array}$ & 4 & $\begin{array}{l}1 \text { - ei nõustu üldse } \\
2 \text { - pigem ei nõustu } \\
3 \text { - pigem nõustun } \\
4 \text { - nõustun täielikult }\end{array}$ & 2016 & 0,56 \\
\hline
\end{tabular}

\section{Andmeanalüïs}

Andmeid analüüsiti parameetriliste testidega, kuna saadud andmed vastavad normaaljaotusele. Esimese uurimisküsimuse juures arvutati SPSS Statisticsi programmi abil üksikküsimuste keskmised ning tehti alaskaalade võrdlustestid (ANOVA dispersioonanalüüs ning t-test). Teisele uurimisküsimusele vastamiseks kasutati SPSS Statisticsi programmis kirjeldavat statistikat (protsentjaotus). 


\section{Tulemused}

Järgnevalt on esitatud tulemused uurimisküsimuste kaupa, kus esimene alapeatükk käsitleb õpetajakoolituse õppekavade sidusust ning teine alapeatükk võimalusi õpetajatöö harjutamiseks.

\section{Õpetajakoolituse õppekavade sidusus}

Esimese uurimisküsimusega püüti leida, kas ja millised erinevused ilmnevad 2014., 2016. ning 2018. aasta üliõpilaste hinnangutes õpetajakoolituse õppekavade sidususele. Tulemustest selgus, et kõikide alaskaalade puhul ilmnes statistiliselt oluline erinevus nii 2014. ja 2016. kui ka 2014. ja 2018. aasta üliõpilaste hinnangute vahel (t-test, $\mathrm{p}<0,05) .2016$. ja 2018. aasta erinevused ei olnud statistiliselt olulised (vt tabel 3).

Tabel 3. Üliõpilaste hinnangud õppekava sidususele 2014., 2016. ja 2018. aasta andmekogumisel

\begin{tabular}{|lccccccc|}
\hline Skaala & Aasta & $\mathbf{n}$ & $\mathbf{M}$ & SD & df & $\mathbf{F}$ & $\mathbf{p}$ \\
\hline II Tajutud sidusus & 2014 & 106 & 2,41 & 0,45 & & & \\
$\quad$ óppeainete vahel & 2016 & 65 & 2,85 & 0,43 & 2 & 26,69 & $0,000^{*}$ \\
& 2018 & 162 & 2,82 & 0,53 & & & \\
\hline III Võimalused & 2014 & 106 & 2,74 & 0,65 & & & \\
$\quad \begin{array}{l}\text { siduda õppekava } \\
\text { eri osi }\end{array}$ & 2016 & 65 & 2,94 & 0,61 & 2 & 6,66 & $0,001^{*}$ \\
$\begin{array}{l}\text { IV Tajutud sidusus } \\
\text { ülikooli ainete ja }\end{array}$ & 2018 & 162 & 3,02 & 0,62 & & & \\
$\quad$ praktika vahel & 2014 & 106 & 2,63 & 0,55 & & & \\
\end{tabular}

Märkused. $\mathrm{M}$ - vastuste keskmine; ${ }^{*} \mathrm{p}<.01 ; \mathrm{df}$ on esitatud gruppidevaheline

Kõige rohkem tõusid hinnangud õppeainete sidususele 2014. aasta $(M=2,41)$ ja 2016. aasta $(M=2,85)$ võrdluses ( $p=0,000$; joonis 2$)$. Järjepidevalt on tõusnud ka üliõpilaste arvamused selle kohta, kui palju on neile antud võimalusi siduda õppekava eri osi. Kui 2014. aastal oli selle alaskaala keskmiseks tulemuseks 2,74, siis 2018. aastal oli see tõusnud 3,02 peale $(\mathrm{p}=0,000)$. Ka ülikooli teoreetiliste õppeainete ning praktikal kogetu vahel tajutud sidususe puhul esineb järjepidev tõus, kui 2014. aastal oli keskmiseks hinnanguks 2,63 ning 2018. aastal 2,95. 


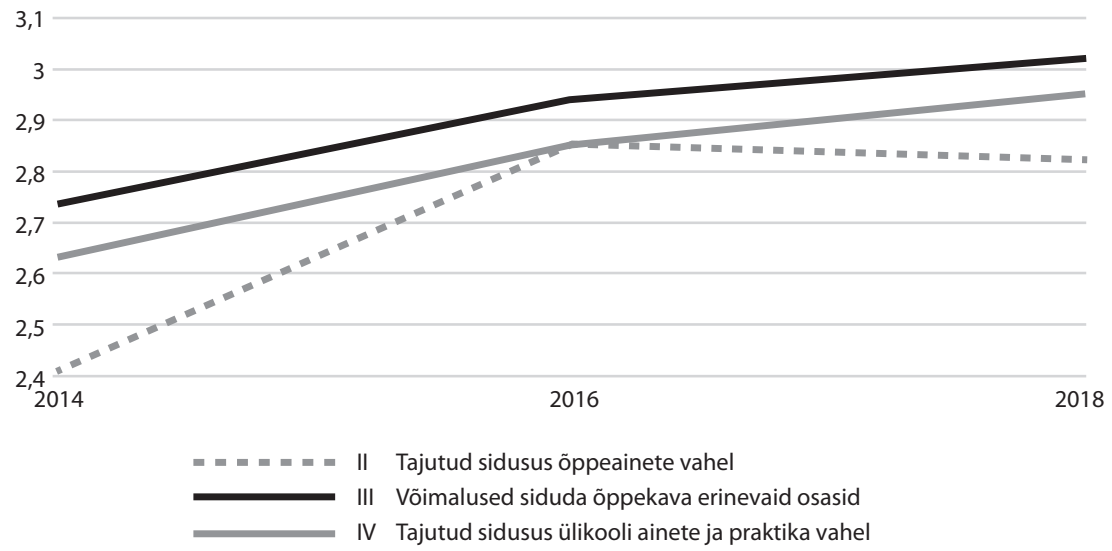

Joonis 2. Üliõpilaste hinnangute (alaskaala keskmine tulemus vastamisskaalal 1-4) muutumist illustreeriv joonis aastate kaupa.

Kõige kõrgemalt üle kõikide alaskaalade hindasid 2018. aasta üliõpilased võimalusi siduda õppekava eri osi. Selle alaskaala puhul hinnati läbi kõikide aastate kõige kõrgemalt võimalusi ,jälgida enda õppimist, reflekteerides, kuidas on muutunud arusaamad õppimisest ja õpetamisest“ (väide D2, tabel 4). Selle küsimuse keskmine hinnang on olnud stabiilselt üle kolme, mis näitab, et üliõpilastel on enda õppimise jälgimiseks ja reflekteerimiseks olnud väga palju võimalusi. Samas alaskaalas sai 2014. ja 2016. aastal madalaima hinnangu küsimus selle kohta, kui palju oli võimalusi „luua seoseid haridusteooriate ja oma õpetamiskogemuste vahel“ (väide E2), samal ajal kui 2018. aastal pälvis madalaima hinnangu võimalused „õppida tundma õpetajakoolituse õppekava aluseks olevat arusaama hea õpetamise kohta" (väide A2).

Kõige madalam hinnang 2018. aastal on aga antud õppeainete vahel tajutud sidususele. Selle alaskaala puhul on kõigil aastatel kõige vähem nõustutud selles, et „õppejõud teadsid, milline ja kui kvaliteetne oli minu praktika“ (väide N3). Kui 2014. aastal oli selle küsimuse keskmine hinnang lausa alla kahe, mis näitab, et suurem osa üliõpilasi õppejõudude teadlikkust nende praktika suhtes ei tajunud, siis 2018. aastaks on keskmine hinnang veidi tõusnud. Samas olid kõikide aastate üliõpilased nõus sellega, et „õpetajakoolituse programmis esitati õpetamise ja õppimise kohta ühtseid põhimõtteid“ (väide B3), mis sai ka alaskaala läbi aastate kõige kõrgema hinnangu.

Kui õppeainete vahel tajutud sidusus 2016. aastast võrreldes 2018. aastaga ei muutunud, siis hinnangud ülikooli õppeainete ja praktika sidususele olid küll paranenud. 2014. aastal nõustuti kõige rohkem väitega „praktikal õpitu ei olnud vastuolus sellega, mida ma õppisin ülikooli õppeainetes“ (väide G3). 2016. ja 2018. aastal hinnati aga kõrgelt väidet „pedagoogilisel praktikal olles 
sain katsetada õpetajakoolituses õpitud teooriaid, õppemeetodeid ja -strateegiaid“" (väide H3). Hoolimata aga võimalusest õpitud teooriaid katsetada, hinnati kõikidel aastatel madalaimaks väidet „pedagoogilisel praktikal täheldasin, et õpetajad kasutavad samu teooriaid, õppemeetodeid ja -strateegiaid, mida õppisin ülikooli õpetajakoolituse õppeainetes“ (väide K3).

Tabel 4. Üliõpilaste hinnangute keskmised alaskaalade väidete kaupa (sulgudes on standardhälve)

\begin{tabular}{|c|c|c|c|c|}
\hline \multirow[b]{2}{*}{ Alaskaala } & \multirow[b]{2}{*}{ Väide } & \multicolumn{3}{|c|}{ Aasta } \\
\hline & & 2014 & 2016 & 2018 \\
\hline \multirow{10}{*}{$\begin{array}{l}\text { II Tajutud sidusus } \\
\text { opppeainete vahel }\end{array}$} & A3 & $2,72(0,58)$ & $3,12(0,59)$ & $3,01(0,64)$ \\
\hline & B3 & $2,85(0,60)$ & $3,22(0,60)$ & $3,06(0,62)$ \\
\hline & $\mathrm{C} 3$ & $1,99(0,77)$ & $2,85(0,72)$ & $2,65(0,81)$ \\
\hline & D3 & $2,50(0,80)$ & $3,03(0,78)$ & $2,82(0,79)$ \\
\hline & E3 & $2,25(0,77)$ & $2,45(0,70)$ & $2,57(0,83)$ \\
\hline & F3 & $2,83(0,63)$ & $3,05(0,64)$ & $3,04(0,69)$ \\
\hline & $J 3$ & $2,27(0,72)$ & $2,94(0,57)$ & $2,90(0,82)$ \\
\hline & L3 & $2,53(0,72)$ & $2,78(0,71)$ & $2,88(0,78)$ \\
\hline & M3 & $2,21(0,78)$ & $2,76(0,81)$ & $2,89(0,83)$ \\
\hline & N3 & $1,98(0,80)$ & $2,35(0,87)$ & $2,41(0,85)$ \\
\hline \multirow{5}{*}{$\begin{array}{l}\text { III Võimalused siduda } \\
\text { õppekava eri osi }\end{array}$} & $\mathrm{A} 2$ & $2,71(0,79)$ & $2,88(0,86)$ & $2,83(0,77)$ \\
\hline & B2 & $2,71(0,90)$ & $2,98(0,84)$ & $3,00(0,76)$ \\
\hline & $\mathrm{C} 2$ & $2,66(0,94)$ & $2,78(0,86)$ & $2,99(0,84)$ \\
\hline & D2 & $3,09(0,79)$ & $3,28(0,82)$ & $3,27(0,83)$ \\
\hline & E2 & $2,51(0,99)$ & $2,78(0,72)$ & $3.01(0,82)$ \\
\hline \multirow{4}{*}{$\begin{array}{l}\text { IV Tajutud sidusus } \\
\text { ülikooli ainete ja } \\
\text { praktika vahel }\end{array}$} & G3_pööratud & $2,84(0,79)$ & $2,93(0,70)$ & $3,06(0,79)$ \\
\hline & $\mathrm{H} 3$ & $2,65(0,91)$ & $3,08(0,73)$ & $3,20(0,69)$ \\
\hline & 13 & $2,55(0,68)$ & $2,80(0,67)$ & $2,91(0,69)$ \\
\hline & K3 & $2,48(0,80)$ & $2,56(0,77)$ & $2,65(0,78)$ \\
\hline
\end{tabular}




\section{Võimalused õpetajatöö olulisi tegevusi harjutada}

Selleks, et saada aru, millised võimalused on üliõpilastel teha õpetaja reaalse tööga samaseid tegevusi ülikooli õppeainetes (sh nende tegevuste analüüsimine ja tagasisidestamine), arvutati CATE küsimustiku esimese alaskaala („Võimalused siduda õpitavat praktilise õpetajatööga“, väited A1-J1) iga väite keskmine hinnang. Iga väite eraldi analüüsimine, vastupidiselt alaskaalaülese tulemuse arvutamisele, annab võimaluse saada võimalikult täpse ja detailse info iga tegevuse kohta eraldi. Joonisel 3 esitatud tulemused näitavad, et hinnangud tegevuste puudumisele on üldjoontes langenud (v.a õpilaste tööde näidiste analüüsimine ja õppetunni videote analüüsimine). Tulemustest selgub, et 2014. aastal puudusid 50\% üliõpilaste hinnangul võimalused oma õpilaste tööde analüüsimiseks. See protsent on küll aastate jooksul vähenenud, kui siiski ka 2018. aasta tulemuste põhjal oli üliõpilastel kõikidest õpetamisega seotud tegevustest kõige vähem võimalusi just enda õpilaste töid analüüsida (33\%). Sarnaselt enda õpilaste tööde analüüsimisega puuduvad üliõpilaste hinnangul ka võimalused üldiselt õpilaste tööde näidiseid analüüsida. See osakaal on küll aastatega kõikunud, kuid 2018. aastal vastas siiski 28\% üliõpilastest, et sellist tegevust nad ülikooli õppeainetes ei teinud. Kolmas tegevus, millele ülikooli ainetes rohkem tähelepanu tuleks pöörata, on klassiruumis toimunud kõne või suhtluse lindistuse analüüsimine. Kui nii 2014. kui ka 2018. aastal vastasid 33-34\% üliõpilastest, et neil polnud üldse võimalust klassiruumis toimunud kõnet analüüsida, oli vahepealsetel aastatel see protsent veelgi suurem (2016. aastal 44\% ning 2017. aastal 38\%).

Kui õpilaste (sh oma õpilaste) tööde ja klassiruumi kõne analüüsimise võimalusi pole kolmandikul uurimuses osalenud üliõpilastest olnud, siis ülejäänud küsimustikus defineeritud tegevuste puhul oli ,ei olnud üldse võimalusi“ vastusevariandi osakaal silmanähtavalt väiksem. Tähelepanu tuleks pöörata ka õppetunni videote analüüsimisele, mille puhul 2018. aastal 17\%-1 üliõpilastest polnud üldse võimalust seda teha. Samuti õppejõu tehtud õpetamise mudeldamisele, mille puhul on võimaluste puudumise hinnang küll pidevalt kehvemaks muutunud, kuid siiski veel 2018. aastal 12\% üliõpilastest polnud õppejõu mudeldamist kogenud. 


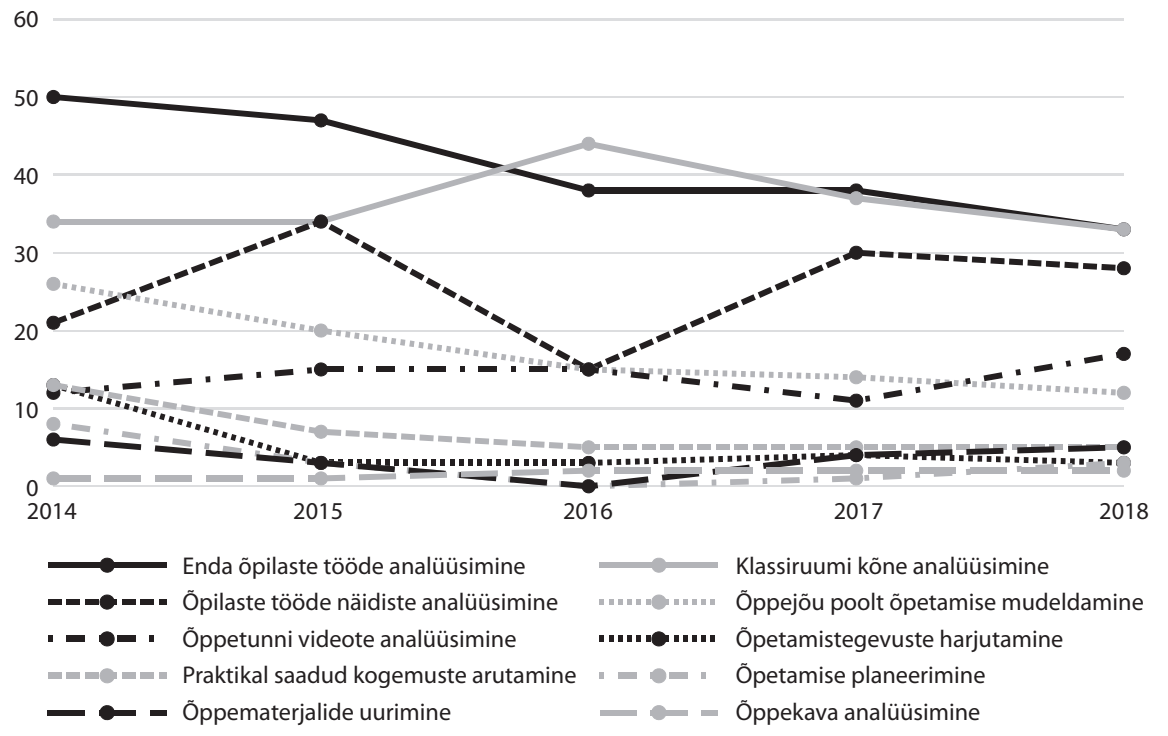

Joonis 3. Üliõpilaste hinnangud võimalustele teha ülikooli õppeainetes praktilise õpetajatööga seotud tegevusi. Joonisel on esitatud vastusevariandi „ei olnud üldse võimalusi“ iga aastakäigu osakaal (\%).

\section{Arutelu}

Siinse uurimuse eesmärk on anda ülevaade Tartu Ülikooli viie aastakäigu (2014-2018) üliõpilaste hinnangutest õpetajakoolituse õppekavade sidususele. Esimese uurimisküsimusega uuriti, millised on üliõpilaste hinnangud õpetajakoolituse óppekavade sidususele ning kas ja kuidas on see muutunud võrreldes 2014., 2016. ja 2018. aasta hinnangutega. Teises uurimisküsimuses analüüsiti lähemalt õpetajatöö praktilisi tegevusi ning leiti, milliseid võimalusi on õpetajakoolituse üliõpilastel ülikooli õppeainetes harjutada õpetajatöö tegevusi ja kuidas on see 2014.-2018. aastal muutunud.

\section{Õpetajakoolituse õppekavade sidusus}

Lähtudes Hammernessi (2006) kirjeldatud jaotusest, võib õppekavade sidusust uurida nii strukturaalse kui ka kontseptuaalse lähenemise kaudu. Kui strukturaalsel tasandil vaadeldakse sidusust kui õppekava loogilist ja terviklikku planeerimist üliõpilaste õppimise toetamiseks, siis siinse uuringu kontekstis puudutasid seda kõige enam üliõpilaste hinnatud võimalused õppekava eri osade sidumiseks. See alaskaala on läbi aastate saanud ka kõige kõrgemad hinnangud, mis näitab Tartu Ülikooli õpetajakoolituse õppekavade head 
sidusust strukturaalsel tasandil. Sama instrumendi abil uuritud õpetajakoolitused Oslos, Stanfordis ja Santiagos näitavad sarnast tulemust, kus võimalusi õppekava osi siduda hinnati üliõpilaste seas kõige kõrgemalt võrreldes ülejäänud sidususe skaaladega (Canrinus et al., 2017).

Uurides aga kontseptuaalset tasandit (Hammerness, 2006), on oluline pöörata tähelepanu õppeaineid läbivale ühtsele visioonile terves õppekavas (sh praktika). Kui siinse uurimuse põhjal on iga aasta õpetajakoolituse sidusus ülikooli õppeainete ja praktika vahel paranenud, on õppeainete omavaheline seostatus saanud üliõpilastelt kõige kehvemaid hinnanguid ning selle alaskaala keskmine on ühtlasi ka 2018. aastaks vähenenud. See tulemus on sarnane Oslo ülikooli üliõpilaste hinnangutega, mida seletati suurte muudatustega andmekogumise ajal (Canrinus et al., 2017). Ka 2014. aastal Eestis korraldati andmekogumine kohe pärast uue alusmooduli esmast rakendumist. Selle aastakäigu üliõpilaste hinnangud õppekava sidususele olid märkimisväärselt madalamad võrreldes näiteks 2016. aastaga. Muudatuste mõju, sealhulgas uute moodulite korralduslik külg ja õppejõudude harjumine uuega, on aeganõudev. Samas on Oslo õpetajakoolituse uurijad toonud välja ettepaneku, et saadud tulemust peaks kontrollima pikemaajalise uuringuga, et saada õppeainete lahknevustele põhjalikumaid vastuseid (Hammerness, 2006). Eestis on seda selle uuringuga tehtud, ent see näitas, et õppeainete omavahelisele seostamisele tuleks järjepidevalt tähelepanu pöörata ning toetada seda, et kõik õpetajakoolituse õppejõud oleksid pidevalt kursis teistes õppeainetes toimunuga.

2018. aastal vastanud üliõpilased olid esimestena läbinud uuendatud praktikaaine, mille abil püütakse koolis tehtavaid praktilisi tegevusi rohkem ülikooli õppetöösse tuua, sealhulgas toetada üliõpilaste reflekteerimisoskusi. Tajutud sidusus ülikooli ainete ja praktika vahel tegigi väikese tõusu 2016. ja 2018. aasta vahel, kuid samas just siis langesid üliõpilaste hinnangud võimalustele siduda õppekava eri osi. See võib viidata asjaolule, et praktikaaine uuendused soodustasid küll kontseptuaalset sidusust, kuid samal ajal pöörati vähem tähelepanu õppekava üldisele struktuurile ja ülesehitusele. Rahvusvaheliste uuringutega võrreldes on aga Eesti tulemus teooria ja praktika sidususe koha pealt pigem rahuldav. Nii Stanfordis, Helsingis, Santiagos kui ka Varonas hinnati teooria ja praktika seostatust ülikooli õppeainetes kõige vähesemaks võrreldes teiste sidususe alaskaaladega. Samas on toodud välja, et praktika osakaalu suurendamine ei tähenda automaatselt praktika ja teooria paremat seostatust, vaid selleks tuleb kahe institutsiooni vahel tihedat koostööd teha (Canrinus et al., 2017). Darling-Hammond, Hammerness, Grossman, Rust ja Shulman (2005) on mitmele uuringule tuginedes leidnud, et koostöös on üks olulisemaid aspekte ühise eesmärgi seadmine ning selle jaoks vajalikes tegevustes kokku leppimine. Koostöö osalisteks on õpetajad koolis, õpetajakoolituse üliõpilased ja juhendajad ülikoolis. 


\section{Võimalused õpetajatöö olulisi tegevusi harjutada}

Üks võimalus teooriat ja praktikat õpetajakoolituses rohkem siduda on tuua rohkem praktilisi klassiruumis toimuvaid tegevusi ülikooli õppeainetesse. See annab üliõpilastele võimaluse neid tegevusi turvalises keskkonnas õppida ja harjutada ning valmistab neid paremini ette mõtestatud tööks koolis (Grossman et al., 2009a). Siinse uurimuse tulemused küll näitasid, et võrreldes varasemaga on 2018. aastaks üliõpilastel rohkem võimalusi teha ülikoolis õpetajatöö tegevusi, kuid endiselt on puudu just klassiruumis toimuvatest tegevustest, nagu õpilaste tööde analüüsimine ja klassiruumis toimunud kõne või õppetunni video analüüsimine. Tegevusi, mida ei tehta otseselt klassiruumis tunni toimumise ajal, on ülikooli õppetöösse rohkem kaasatud (nt õppetunni planeerimine ja õppekava analüüsimine). See tulemus on hästi kooskõlas Canrinuse et al. (2019) leituga, kus Oslo, Stanfordi, Helsingi, Santiago ja Varona õpetajakoolituse üliõpilased tunnistasid kõige vähem võimalusi klassiruumi kõne ja õpilastööde näidiste analüüsimiseks, samal ajal kui kõige rohkem oli neil võimalusi ülikoolis harjutada õppetöö planeerimist, analüüsida õppekavasid ja arutleda praktikal saadud kogemuste üle. Lisaks on saadud tulemus kooskõlas ka Jenseti, Canrinuse, Klette ja Hammernessi (2018a) tulemusega, kus vaatluste abil selgitati välja, et üliõpilastele pakuti ülikooli õpingute ajal väga vähe võimalusi laste õppimise analüüsimiseks.

Samas on argumenteeritud, et just õpilase õppimisele toetuv lähenemine on eduka õpetamise alus (Hammerness \& Klette, 2015). Õpetajakoolitus on aga üha rohkem keskendunud klassi juhtimise küsimustele ning õppimine ja areng on jäänud tagaplaanile (Grossman et al., 2009a). Seda kinnitab ka hiljuti Eestis korraldatud uuring, kus selgus, et nii õpetajakoolituste üliõpilastel kui ka töötavatel õpetajatel on kõige kehvemad teadmised just laste õppimise ja arengu kohta käivates üldpedagoogiliste teadmiste valdkonnas (Malva, Linde, Poom-Valickis, \& Leijen, 2018; Malva, Leijen, \& Baucal, 2019; Malva, Leijen, $\&$ Baucal, 2020).

Toetudes siinse uurimuse hinnangutele, on aastate jooksul suurenenud õppejõudude tehtav õpetamise mudeldamine. Korthageni, Loughrani ja Russelli (2006) järgi on õpetajakoolituse üks fundamentaalseid printsiipe just õppejõudude ette näidatud õpetamise ja õppimise olukorrad, mis tuginevad kogu õpetajakoolituse ühisele vaatele õpetamise kohta. Õppejõududel on oluline roll õpetajakoolituse ühtse visiooni rakendumisel. Varem on kritiseeritud töötavate õpetajate liigset koolikesksust ning praktikale ja intuitsioonile tuginevat õpetamisviisi, samal ajal kui õppejõudude juures on täheldatud praktilisest elust eemaldumist ehk teooriakesksust (Hammerness, 2013; Korthagen, 2001). Õppejõudude tehtav õpetamise mudeldamine on üliõpilastele heaks kinnituseks neid õpetavate professionaalide kompetentsi kohta õpetajatöös, samuti aitaks see vähendada ülikoolis õpitu ja koolis kogetu erinevusi. 


\section{Piirangud ja edasine uurimistöö}

Siinne uurimus andis ülevaate õpetajakoolituse õppekavade sidususe ning teooria ja praktika kooskõla kohta. Välja toodi ka konkreetsed tegevused ning üliõpilaste võimalused neid tegevusi õpingute ajal teha. Kuna küsimustikus on esitatud valikvastustega väited, ei anna uurimus ülevaadet nende tegevuste sisu kohta. Seetõttu tuleks edaspidi Jenseti jt (2018a) soovitusel uurida ka nende tegevuste kvaliteeti, mis annaks veelgi enam tagasisidet ópetajatöö praktiliste tegevuste rakendumisest ülikooli õppetöös. Seejärel tuleks eraldi vaadelda tulemusi nii õppekavade kui ka -astmete kaupa, kuna ainedidaktika óppeained on kõigil erinevad. Siinses uuringus seda tehtud pole, kuna väga erinev valimite suurus õppekavade ja -astmete kaupa piirab statistilise andmeanalüüsi võimalusi. Küll aga saaks tulevikus enesekohase küsimustiku tulemusi täiendada intervjuudega õpingute lõpus, et paremini mõista üliõpilaste kogemusi teooria ja praktika seostamisega ülikooli õpingute ajal.

\section{Kasutatud kirjandus}

Anspal, T., Leijen, Ä., \& Löfström, E. (2019). Tensions and the teacher's role in student teacher identity development in primary and subject teacher curricula. Scandinavian Journal of Educational Research, 63(5), 679-695. https://doi.org/10.1080/00313831.2017.1420688

Ball, D., \& Forzani, F. M. (2009). The Work of Teaching and the Challenge for Teacher Education. Journal of Teacher Education, 60(5), 497-511. https://doi.org/10.1177/0022487109348479

Boyd, D., Grossman, P., Lankford, H., Loeb, S., \& Wyckoff, J. (2006a). How Changes in Entry Requirements Alter the Teacher Workforce and Affect Student Achievement. Education Finance and Policy, 1(2), 176-216. https://doi.org/10.1162/edfp.2006.1.2.176

Boyd, D. J., Grossman, P., Lankford, H., Loeb, S., Michelli, N. M., \& Wyckoff, J. (2006b). Complex by design: Investigating pathways into teaching in New York City schools. Journal of Teacher Education, 57, 155-166. https://doi.org/10.1177/0022487105285943

Boyd, D. J., Grossman, P. L., Lankford, H., Loeb, S., \& Wyckoff, J. (2009). Teacher Preparation and Student Achievement. Educational Evaluation and Policy Analysis, 31(4), 416-440. https://doi.org/10.3102/0162373709353129

Buchman, M., \& Floden, R. E. (1991). Programme coherence in teacher education: a view from the USA. Oxford Review of Education, 17, 65-72. https://doi.org/10.1080/0305498910170105

Canrinus, E. T., Bergem, O. K., Klette, K., \& Hammerness, K. (2017). Coherent Teacher Education Programmes: Taking a Student Perspective. Journal of Curriculum Studies, 49(3), 313-333. https://doi.org/10.1080/00220272.2015.1124145 
Canrinus, E. T., Klette, K., Hammerness, K., \& Bergem, O. K. (2019). Opportunities to enact practice in campus courses: Taking a student perspective. Teachers and Teaching, 25(1), 110-124. https://doi.org/10.1080/13540602.2018.1526171

Darling-Hammond, L. (1999). America's future: Educating teachers. Education Digest, 64(9), 18-23.

Darling-Hammond, L. (2014). Strengthening clinical preparation: The holy grail of teacher education. Peabody Journal of Education, 89(4), 547-561. https://doi.org/10.1080/0161956X.2014.939009

Darling-Hammond, L., Hammerness, K., Grossman, P., Rust, F., \& Shulman, L. (2005). The design of teacher education programmes. In L. Darling-Hammond \& J. Brandsford (Eds.), Preparing teachers for a changing world. What teachers should learn and be able to do (pp. 390-441). San Francisco, CA: Jossey-Bass.

Grossman, P., Compton, C., Igra, D., Ronfeldt, M., Shahan, E., \& Williamson, P. W. (2009a). Teaching Practice: A Cross-Professional Perspective. Teachers College Record, 111(9), 2055-2100.

Grossman, P., Hammerness, K., \& McDonald, M. (2009b). Redefining teaching, reimagining teacher education. Teachers and Teaching, 15(2), 273-289. https://doi.org/10.1080/13540600902875340

Grossman, P., Hammerness, K., McDonald, M., \& Ronfeldt, M. (2008). Constructing Coherence: Structural Predictors of Perceptions of Coherence in NYC Teacher Education Programs. Journal of Teacher Education, 59(4), 273-287. https://doi.org/10.1177/0022487108322127

Grossman, P., \& Loeb, S. (2010). Learning From Multiple Routes. Educational Leadership, 22-27.

Grossman, P., \& McDonald, M. (2008). Back to the Future: Directions for Research in Teaching and Teacher Education. American Educational Research Journal, 45(1), 184-205. https://doi.org/10.3102/0002831207312906

Hammerness, K. (2006). From Coherence in Theory to Coherence in Practice. Teachers College Record, 108(7), 1241-1265.

https://doi.org/10.1111/j.1467-9620.2006.00692.x

Hammerness, K. (2013). Examining Features of Teacher Education in Norway. Scandinavian Journal of Educational Research, 57(4), 400-419. https://doi.org/10.1080/00313831.2012.656285

Hammerness, K., \& Klette, K. (2015). Indicators of quality in teacher education: Looking at features of teacher education from an international perspective. In G. K. LeTendre \& A. W. Wiseman (Eds.), Promoting and sustaining a quality teaching workforce (pp. 239-277). Bingley, UK: Emerald Group Publishing Limited.

Hammerness, K., Klette, K., \& Bergem, O. K. (2014). Coherence and assignments in teacher education: Teacher education survey. Oslo, Norway: University of Oslo Department of Teacher Education and School Research.

Jenset, I. S., Canrinus, E. T., Klette, K., \& Hammerness, K. (2018a). Opportunities to analyse pupils' learning within coursework on campus: a remaining challenge in teacher education. European Journal of Teacher Education, 41(3), 360-376. https://doi.org/10.1080/02619768.2018.1448783 
Jenset, I. S., Klette, K., \& Hammerness, K. (2018b). Grounding teacher education in practice around the world: An examination of teacher education coursework in teacher education programs in Finland, Norway, and the United States. Journal of Teacher Education, 69(2), 184-197. https://doi.org/10.1177/0022487117728248

Klette, K., Hammerness, K., \& Jenset, I. S. (2017). Established and evolving ways of linking to practice in teacher education: Findings from an international study of the enactment of practice in teacher education. Acta Didactica Norge, 11(3), Art-9. https://doi.org/10.5617/adno.4730

Korthagen, F. (2001). Linking Practice and Theory: the Pedagogy of Realistic Teacher Education. Paper presented at the Annual Meeting of the American Educational Research Association, Seattle.

Korthagen, F., Loughran, J., \& Russell, T. (2006). Developing fundamental principles for teacher education programs and practices. Teaching and Teacher Education, 22, 1020-1041. https://doi.org/10.1016/j.tate.2006.04.022

Kraut, R. E., Fussell, S. R., Brennan, S. E., \& Siegel, J. (2002). Understanding effects of proximity on collaboration: Implications for technologies to support remote collaborative work. In P. J. Hinds \& S. Kiesler (Eds.), Distributed work (pp. 137162). London: MIT Press.

Leijen, Ä., Kullasepp, K., \& Ots, A. (2013). Õpetaja professionaalse rolli internaliseerimise hindamine õpetajakoolituse esmaõppe üliõpilaste hulgas. Eesti Haridusteaduste Ajakiri, 1, 72-96. https://doi.org/10.12697/eha.2013.1.05

Leijen, Ä., \& Pedaste, M. (2018). Pedagogical Beliefs, Instructional Practices, and Opportunities for Professional Development of Teachers in Estonia. In: Niemi, H.; Toom, A.; Kallioniemi, A.; Lavonen, J. (Ed.). The Teacher's Role in the Changing Globalizing World (33-46). BRILL. https://doi.org/10.1163/9789004372573_003

Krull, E. (2003). Pedagoogiline koolipraktika kui otsustav tegur õpetajakoolituse asjakohastamisel. E. Krull \& K. Oras (Toim). Õpetajate professionaalne areng ja õppepraktika (lk 47-63).

Malva, L. (2015). Õppeainete ning teooria ja praktika sidusus Tartu Ülikooli õpetajakoolituse óppekavades. Magistritöö. Tartu Ülikool, Haridusteaduste instituut.

Malva, L., Leijen, A., \& Baucal, A. (2019). Measuring pre-service teachers' general pedagogical knowledge - What are the results telling?. New Trends and Issues Proceedings on Humanities and Social Sciences, 6(1), 135-144.

https://doi.org/10.18844/prosoc.v6i1.4164

Malva, L., Leijen, Ä., \& Baucal, A. (2020). Towards measuring teachers' general pedagogical knowledge - A mixed method investigation of a pilot test. Studies in Educational Evaluation, 64. https://doi.org/10.1016/j.stueduc.2019.100815

Malva, L., Linde, M., Poom-Valickis, K. \& Leijen, Ä. (2018). OECD ópetaja pedagoogiliste teadmiste pilootuuringu Eesti raport. Haridus- ja Teadusministeerium.

Muller, J. (2009). Forms of knowledge and curriculum coherence. Journal of Education and Work, 22, 205-226. https://doi.org/10.1080/13639080902957905

Newmann, F. M., Smith, B., Allensworth, E., \& Bryk, A. S. (2001b). School instructional program coherence: Benefits and challenges. Chicago, IL: Consortium on Chicogo school research. 
Pedaste, M., Pedaste, K., Lukk, K., Villems, P., \& Allas, R. (2013). A Model of Innovation Schools: Estonian Case-study. Procedia - Social and Behavioral Sciences, 112, 418-427. https://doi.org/10.1016/j.sbspro.2014.01.1184

Poom-Valickis, K., \& Löfström, E. (2014). Pikiuuring õpetajaks õppijate professionaalse identiteedi kujunemisest. Eesti Haridusteaduste Ajakiri, 241-271. https://doi.org/10.12697/eha.2014.2.1.10

Prosser, M., Ramsden, P., Trigwell, K., \& Martin, E. (2003). Dissonance in experience of teaching and its relation to the quality of student learning. Studies in Higher Education, 28(1), 37-48. https://doi.org/10.1080/03075070309299

Raudenbush, S. W. (2008). Advancing educational policy by advancing research on instruction. American Educational Research Journal, 25, 206-230. https://doi.org/10.3102/0002831207312905

Stürmer, K., Könings, K. D., \& Seidel, T. (2013). Declarative knowledge and professional vision in teacher education: effect of courses in teaching and learning. British Journal of Educational Psychology, 83(3), 467-483. https://doi.org/10.1111/j.2044-8279.2012.02075.x

Zeichner, K. (2010). Rethinking the connections between campus courses and field experiences in college- and university-based teacher education. Journal of Teacher Education, 61, 89-99. https://doi.org/10.1177/0022487109347671

Tatto, M. T. (1996). Examining Values and Beliefs About Teaching Diverse Students: Understanding the Challenges for Teacher Education. Educational Evaluation and Policy Analysis, 18, 155-180. https://doi.org/10.3102/01623737018002155 


\section{Lisa A: CATE küsimustik}

1. Võttes arvesse oma õpetajakoolituse alusmooduli aineid, kui palju oli teil võimalusi teha järgnevaid tegevusi? Palun märkige iga rea kohta üks vastus.

1 - polnud üldse võimalusi

4 - oli väga palju võimalusi

A1 Planeerida õpetamist (töötada välja töökava, tunnikava ja õppematerjalid).

B1 Harjutada tegevust, mida planeerisite õpilastega klassiruumis teha (nt harjutada plaanitava tunni sissejuhatuse või õpilastele tagasiside andmist, rollimäng).

C1 Analüüsida õpilaste tööde näidiseid.

D1 Analüüsida enda õpilaste töid.

E1 Uurida kasutusel olevaid õppematerjale (kooli õppekava, töökavade või tundide näidised õpetajatelt).

F1 Analüüsida riiklikku õppekava, kooli õppekava, kutsestandardit ning teisi juhendeid.

G1 Analüüsida klassiruumis toimunud kõne või õpilaste arutelu transkriptsiooni.

H1 Vaadata või analüüsida õppetundide videoid.

I1 Arutleda õppeainetes pedagoogilisel praktikal saadud õpetamiskogemuste üle.

J1 Kogeda õpetajakoolituse õppejõu efektiivse õpetamise praktika mudeldamist, demonstreerimist.

2. Mõeldes oma õpetajakoolituse alusmoodulist saadud kogemustele, kui palju on teil olnud võimalusi teha järgmisi tegevusi? Palun märkige iga rea kohta üks vastus.

1 - polnud üldse võimalusi

4 - oli väga palju võimalusi

A2 Õppida tundma õpetajakoolituse õppekava aluseks olevat arusaama hea õpetamise kohta.

B2 Luua seoseid ühe õppeaine erinevate teemade vahel.

C2 Luua seoseid erinevates õppeainetes õpetatavate teemade vahel.

D2 Jälgida enda õppimist, reflekteerides, kuidas on muutunud teie arusaamad õppimisest ja õpetamisest.

E2 Luua seoseid haridusteooriate ja oma õpetamiskogemuste vahel. 
3. Mõeldes oma senistele õpingutele õpetajakoolituse alusmooduli raames, mil määral te nõustute või ei nõustu järgmiste väidetega? Palun märkige iga rea kohta üks vastus.

1 - Ei nõustu üldse

2 - Pigem ei nõustu

3 - Pigem nõustun

4 - Nõustun täielikult

A3 Õpetajakoolituse programm kannab terviklikku nägemust heast õpetamisest ja õppimisest.

B3 Õpetajakoolituse programmis esitati õpetamise ja õppimise kohta ühtseid põhimõtteid.

C3 Õppejõud olid kursis õppekava teistes ainetes toimunuga (nt ülesanded, käsitletav kirjandus, põhiideed).

D3 Õppeained olid kavandatud nii, et terviklik arusaam kujunes järk-järgult.

E3 Kui lähtekohad või õpitu mõnes õppeaines kordus, siis käsitleti neid järgmisel kursusel sügavamalt.

F3 Ma tajusin seoseid ideede ja kontseptsioonide vahel, mida õppeainetes käsitleti.

G3 Praktikal õpitu oli vastuolus sellega, mida ma õppisin ülikooli õppeainetes.

H3 Pedagoogilisel praktikal olles sain katsetada õpetajakoolituses õpitud teooriaid, õppemeetodeid ja -strateegiaid.

I3 Õppeainetes õpitu peegeldas seda, mida ma kogesin praktikal.

J3 Õppejõud olid teadlikud õpetajakoolituse programmist kui tervikust.

K3 Pedagoogilisel praktikal täheldasin, et õpetajad kasutavad samu teooriaid, õppemeetodeid ja -strateegiaid, mida õppisin ülikooli õpetajakoolituse õppeainetes.

L3 Õppejõud viitasid oma kursustel ka teistele õppeainetele.

M3 Õppejõud teadsid, mida ma pean pedagoogilise praktika ajal tegema.

N3 Õppejõud teadsid, milline ja kui kvaliteetne oli minu praktika. 


\title{
A cross-sectional study on the University of Tartu's pre-service teachers' perceptions of curriculum coherence between 2014 and 2018
}

\author{
Liina Malva ${ }^{a 1}$, Äli Leijen ${ }^{a}$ \\ ${ }^{a}$ Institute of Education, University of Tartu
}

\section{Summary}

\section{Introduction}

Coherence is an important characteristic of a high quality teacher educational programme which, if organised purposefully, means that the courses are structured and aimed at a certain outcome (Hammerness, 2013). Coherence can be seen from two perspectives: coherence of the courses and coherence of theory and practice. Hammerness (2006; see also Muller, 2009) has emphasised that within the coherence of courses we should look at both approaches, structural and conceptual coherence. The former is important for organising university courses in a logical order, so that each course would increase the students' knowledge. The latter approach looks at the content of those courses, more specifically, at a successive common vision about teaching.

The conceptual coherence becomes especially important when students do their fieldwork. If the university educators have shared a common vision about teaching, students will experience their fieldwork more meaningfully and are able to make better connections (Hammerness, 2006; Tatto, 1996). Consequently, the ideas gained from theoretical courses should be strongly in line with fieldwork experiences (Darling-Hammond, 1999; Grossman, Hammerness, McDonald, \& Ronfeldt, 2008). A good fieldwork school should support students in terms of what they have studied at the university (Hammerness, 2013).

In order to strengthen the coherence of teacher education programmes, Grossman and McDonald (2008) have developed a concept of core practices, the most important activities that teachers carry out in their everyday work. These activities should determine the framework of the teacher education programme in order to support students' professional knowledge, skills and identity. According to Grossman, Hammerness and McDonald (2009b) core

Institute of Education, University of Tartu, Salme 1a, Tartu 50103 Estonia; liina.malva@ut.ee 
practices are activities that: 1 ) appear often in teaching; 2) provide the possibility to develop; and 3) are based on empirical research.

After defining these activities, a coherent teacher education programme should provide opportunities for students to practice them. It has been found that teachers who had more opportunities to try out different teaching activities during their studies were also more effective during their first year of teaching (Boyd, Grossman, Lankford, Loeb, \& Wyckoff, 2006).

Since 2013 the teacher education programmes at the University of Tartu (Estonia) have gone through several extensive changes. The first change took place in 2013 when the base module and fieldwork module of teacher education were completely renewed. Achieving a better connection between theoretical studies and fieldwork was addressed by 1) organising courses that are taught by larger teams of teacher educators in order to enable more cooperation; and 2) to increase opportunities and the amount of fieldwork. The second significant change came in 2017 when one of the fieldwork courses was fully renewed and the concept of core practices was applied. The fieldwork course was now in coherence with the base module through common activities and topics that would support students to try out and analyse more teaching activities.

The aim of this article is to investigate the opinions of student teachers at the University of Tartu regarding the coherence of their teacher education programmes. Two research questions were addressed:

1) In the opinion of the student teachers, how coherent were the teacher education programmes in 2014, 2016 and 2018 at the University of Tartu?

2) What opportunities did the student teachers have to practice teaching activities during the university courses between 2014 and 2018 ?

\section{Methodology}

Sample. Data were collected in $2014(\mathrm{n}=106), 2015(\mathrm{n}=102), 2016(\mathrm{n}=63), 2017$ $(n=136)$ and $2018(n=165)$ from teacher education students who were finishing their base module and fieldwork module studies. Students were studying at Bachelor's level (e.g. special education, vocational teacher) or Master's level (e.g. foreign language teachers, art teachers, science teachers). In the latter case the students took up teacher education studies at Master's level after completing the subject at Bachelor's level. Participation in the data collection was voluntary.

Instrument. A CATE (Coherence and Assignment Practices in Teacher Education; (Hammerness, Klette \& Bergem, 2014) questionnaire was used in order to collect data about 1) opportunities to enact practices; 2) perceived 
coherence between courses; 3 ) opportunities to connect different parts of the programme; and 4) perceived coherence between university courses and fieldwork. In these four constructs the CATE questionnaire included 29 items. The respondents had to indicate their opinions on a four-point scale. Reliability was measured using Cronbach, where $a$ was between $0.78-0.88$ for the second and third constructs which was considered good. The reliability of the fourth construct was $0.56-0.63$ which was moderate. The first construct was analysed on the item level.

Data analysis. Data analysis was carried out using SPSS, and descriptive statistics were used, in addition to t-test and ANOVA, for comparing different years.

\section{Results and discussions}

The results of the first research question showed that there was a significant increase in the students' ratings between years 2014 and 2016. While the ratings for opportunities to connect different parts of the programme and the perceived coherence between university courses and fieldwork kept increasing until 2018, the perceived coherence between courses showed a small decline. By 2018 the ratings for the opportunities to connect parts of the programme were the highest among all constructs (mean $=3.02 ; \mathrm{SD}=0.62$ ) which shows a good structural coherence. The same result was found by Canrinus, Bergem, Klette and Hammerness (2017) in teacher education institutes in Oslo (Norway), Stanford (USA) and Santiago (Chile).

Despite that, the students perceived the coherence between courses as the lowest of all constructs (in 2014 mean $=2.41$ and $\mathrm{SD}=0.45$; in $2018 \mathrm{~m}=2.82$ and $\mathrm{SD}=0.53$ ). The analysis on the item level showed that students agree the least that "our teacher educators were knowledgeable about what I was required to do in my field teaching experience". Based on Hammerness (2006), the conceptual coherence of the programme could be improved by sharing a common vision throughout all courses, including fieldwork. Similar result was also found in Oslo (Canrinus et al., 2017) and the researchers explained that this was the result of constant and ongoing changes in their teacher education programmes. Also, at the University of Tartu several changes have taken place during the data collection. Rapid changes can cause misunderstandings in the courses' organisation and getting used to new programmes takes time. However, the results show that the coherence of different courses should get more attention. 
The coherence of theoretical courses and fieldwork can be considered as satisfactory (in 2018 mean $=2.95 ; \mathrm{SD}=0.49$ ) when compared to international results measured with the same instrument. The students in Stanford, Santiago and Helsinki rated this construct as the lowest (Canrinus et al., 2017). As these institutions had increased the amount of fieldwork, the researchers argued that this does not automatically lead to coherence in theory and practice.

One option to enhance the connection between theory and practice is to include more practical tasks to university coursework. Our results of the second research question showed that in the students' opinion their studies lack opportunities to analyse pupils' work and have classroom discussions (recordings and videos). This result agrees with the findings of Canrinus, Klette, Hammerness and Bergem (2019) in Oslo, Stanford, Helsinki, Santiago and Varona (Cuba). These activities are most directly connected to classroom teaching, while activities not related to classwork, were found to get more attention during the university courses at the University of Tartu as well as in the Canrinus et al. (2019) study (e.g. analysing curricula, plan for teaching). It has been argued that teaching that is based on the learners' needs is more efficient in terms of the pupils' development (Hammerness \& Klette, 2015), however, teacher education courses at the university focus more on questions of classroom management than learning and development (Grossman et al., 2009a).

In brief, the results of the current study indicate several possibilities for improving the coherence of teacher education at the University of Tartu. In addition to this, the results confirm previous empirical studies which argue that teacher education should focus more on pupils' learning in order to prepare teachers for efficient teaching.

Keywords: teacher education, teacher education courses and practice, curriculum coherence 